\title{
Article
}

\section{Kombucha Tea as a Reservoir of Cellulose Producing Bacteria: Assessing Diversity among Komagataeibacter Isolates}

\author{
Salvatore La China (D), Luciana De Vero (D), Kavitha Anguluri, Marcello Brugnoli, Dhouha Mamlouk \\ and Maria Gullo *iD
}

check for updates

Citation: La China, S.; De Vero, L.; Anguluri, K.; Brugnoli, M.; Mamlouk, D.; Gullo, M. Kombucha Tea as a Reservoir of Cellulose Producing Bacteria: Assessing Diversity among Komagataeibacter Isolates. Appl. Sci. 2021, 11, 1595. https://doi.org/ 10.3390/app11041595

Academic Editor: Maria Kanellaki

Received: 31 December 2020

Accepted: 6 February 2021

Published: 10 February 2021

Publisher's Note: MDPI stays neutral with regard to jurisdictional claims in published maps and institutional affiliations.

Copyright: (c) 2021 by the authors. Licensee MDPI, Basel, Switzerland. This article is an open access article distributed under the terms and conditions of the Creative Commons Attribution (CC BY) license (https:// creativecommons.org/licenses/by/ $4.0 /)$.
Department of Life Sciences, University of Modena and Reggio Emilia, 42122 Reggio Emilia, Italy; salvatore.lachina@unimore.it (S.L.C.); luciana.devero@unimore.it (L.D.V.); kavitha.anguluri@unimore.it (K.A.); marcello.brugnoli96@gmail.com (M.B.); mamloukdhouha@gmail.com (D.M.)

* Correspondence: maria.gullo@unimore.it

Abstract: Bacterial cellulose (BC) is receiving a great deal of attention due to its unique properties such as high purity, water retention capacity, high mechanical strength, and biocompatibility. However, the production of $\mathrm{BC}$ has been limited because of the associated high costs and low productivity. In light of this, the isolation of new BC producing bacteria and the selection of highly productive strains has become a prominent issue. Kombucha tea is a fermented beverage in which the bacteria fraction of the microbial community is composed mostly of strains belonging to the genus Komagataeibacter. In this study, Kombucha tea production trials were performed starting from a previous batch, and bacterial isolation was conducted along cultivation time. From the whole microbial pool, 46 isolates were tested for their ability to produce $\mathrm{BC}$. The obtained BC yield ranged from $0.59 \mathrm{~g} / \mathrm{L}$, for the isolate $\mathrm{K} 2 \mathrm{G} 36$, to $23 \mathrm{~g}$ / $\mathrm{L}$ for $\mathrm{K} 2 \mathrm{G} 30$ - which used as the reference strain. The genetic intraspecific diversity of the 46 isolates was investigated using two repetitive-sequence-based PCR typing methods: the enterobacterial repetitive intergenic consensus (ERIC) elements and the (GTG) 5 sequences, respectively. The results obtained using the two different approaches revealed the suitability of the fingerprint techniques, showing a discrimination power, calculated as the D index, of 0.94 for (GTG) 5 rep-PCR and 0.95 for ERIC rep-PCR. In order to improve the sensitivity of the applied method, a combined model for the two genotyping experiments was performed, allowing for the ability to discriminate among strains.

Keywords: kombucha tea; microbial diversity; bacterial cellulose; Komagataeibacter xylinus; repetitive elements sequence-based rep-PCR; typing

\section{Introduction}

The attraction of bacterial cellulose (BC) as a natural biopolymer, produced by microorganisms, arises from its main functional properties and subsequent applications, especially in the biomedical, food, and engineering fields [1-3]. Bacteria able to synthesize cellulose can be considered ubiquitous since they have been found to inhabit different ecosystems. They can be isolated from environmental sources (such as soil and plants), from insects, humans, and from food sources [4].

Within the family Acetobacteraceae, the genus Komagataeibacter includes species, such as K. xylinus, K. europaeus and K. hansenii, that have been described as cellulose producing organisms [5]. The main studied strains belong to the K. xylinus species, which is recognized as the model organism for studying the mechanism of BC synthesis [6,7].

One of the most important reservoirs in which it is possible to detect strains belonging to the Komagataeibacter genus is kombucha tea, a fermented beverage traditionally produced in Asia, probably originating from the northeast of China [8]. Kombucha tea is characterized by a microbial community in which different microbial groups, mainly yeasts and bacteria, live in a symbiotic lifestyle [9]. Among bacteria groups, acetic acid 
bacteria are the main functional organisms, although lactic acid bacteria are also found; moreover, among yeasts, strains of the genera Saccharomyces and Zygosaccharomyces have been described [10]. Kombucha tea production consists of two fermentation reactions operated by yeasts and acetic acid bacteria [11]. The symbiotic relation between yeast and bacteria is established during the fermentation process, in which the yeasts are capable of hydrolysing sucrose, the main substrate for kombucha tea production, into glucose and fructose, and then ethanol. Acetic acid bacteria use glucose, fructose and ethanol to produce gluconic acid, glucuronic acid, acetic acid, and BC [12,13].

Kombucha tea can be considered as a dynamic environment, rapidly changing its composition, acting as an ecophysiological reservoir of very specialized organisms. Considering the occurrence and function of acetic acid bacteria within kombucha, previous studies have described K. xylinus as the main species.

The ability of K. xylinus strains to produce $\mathrm{BC}$ is highly variable, making the selection of the best ones a crucial step in order to obtain candidate strains for large scale BC production. In fact, the availability of selected organisms in producing $\mathrm{BC}$ is a requirement for exploiting them as industrial machinery. The production of $\mathrm{BC}$ is mainly influenced by two factors. The first one is represented by the carbon sources used in the medium [14,15]; pure carbon sources could increase the production cost, making the process unsustainable. The second issue is related to the ability of the organism to grow and produce $\mathrm{BC}$ in the selected conditions [16]. Some studies have described the abilities of strains belonging to the Komagataeibacter genus for producing BC at different yields [5].

In this work, acetic acid bacteria were collected from liquid and pellicle fraction of kombucha tea samples. In total, 46 isolates were screened for their ability to produce BC and for the main phenotypic characteristics. Moreover, they were typed by applying a fingerprint analysis based on (GTG) 5 repetitive elements and Enterobacterial Repetitive Intragenic Consensus (ERIC) elements in order to assay the intraspecific genetic diversity.

\section{Materials and Methods}

\subsection{Kombucha Preparation, Sampling and Physico-Chemical Determinations}

Two native local kombucha precultures (P1 and P2) were provided by the National Institute of Applied Sciences and Technology (INSAT, Tunisia), previously cultivated on two different substrates: black tea (P1) and green tea (P2). Each preculture was composed of kombucha cellulose pellicle with approximately $200 \mathrm{~mL}$ of starter culture. Duplicates of kombucha, referred to green tea kombucha (GTK) and black tea kombucha (BTK), were prepared and inoculated according to Jayabalan et al. [17]. Briefly, sucrose $10 \%(w / v)$ was added to demineralized water and allowed to boil. Afterwards, $1.2 \%(w / v)$ black or green tea (Les Jardins du thé, Office Tunisien du Commerce, Tunisia) was added and allowed to infuse for about $5 \mathrm{~min}$. After filtration of tea leaves through a sterile sieve, $200 \mathrm{~mL}$ of tea was poured into $500 \mathrm{~mL}$ glass jars that had been previously sterilized at $+121{ }^{\circ} \mathrm{C}$ for $20 \mathrm{~min}$. Once the sucrose-tea solution had cooled at room temperature, $10 \%(v / v)$ of the fermented tea (of the previous fermentation brew from kombucha with the same origin, in this case black or green tea as substrate, corresponding to the aforementioned starter culture) was added. Then, $3 \%(w / v)$ of representative pellicle fragments cut from the preculture were placed in the culture light side up. The jars were covered with a sterile gauze and fixed with an elastic band. Fermentations were carried out in the dark for 12 days. All experiments were carried out aseptically.

Cell morphology and direct observation of samples were carried out using optical microscopy at $100 \times$ of magnification, using C. Zeiss microscope apparatus (Axiolab).

Titratable acidity was determined by neutralizing samples at $\mathrm{pH} 7.2$ with $0.1 \mathrm{~N}$ of $\mathrm{NaOH}$ (it was assumed that all media acidity was due to acetic acid) and expressed as \% $(w t / w t) ; \mathrm{pH}$ was measured by CRISON, MicropH, $2002 \mathrm{pHmeter}$. Ethanol, expressed as \% $(v / v)$, was checked by densitometry measure using a hydrostatic balance after distillation. 


\subsection{Plating and Isolation}

Plating was performed immediately after sampling. Therefore, $10 \mathrm{~mL}$ of $0.1 \%(w / v)$ peptone water was added to $1 \mathrm{~g}$ of black or green kombucha pellicle in a sterile stomacher bag that was vigorously shaken for $5 \mathrm{~min}$ in a laboratory blender STOMACHER ${ }^{\circledR} 400$ (Seward, England) to obtain a uniform homogenate. Samples (1 mL each) of the homogenate and liquid phase were 10 -fold serially diluted in $0.1 \%(w / v)$ peptone water, from which aliquots $(0.1 \mathrm{~mL})$ were plated on GYC medium $(50 \mathrm{~g} / \mathrm{L}$ glucose, $10 \mathrm{~g} / \mathrm{L}$ yeast extract, $15 \mathrm{~g} / \mathrm{L} \mathrm{CaCO}_{3}, 9 \mathrm{~g} / \mathrm{L}$ bacteriological agar) and $\mathrm{ACB}$ agar medium $(30 \mathrm{~g} / \mathrm{L}$ yeast extract, $1 \mathrm{~mL}$ of a $22 \mathrm{~g} / \mathrm{L}$ bromocresol green solution, $20 \mathrm{~g} / \mathrm{L}$ bacteriological agar). The media were previously autoclaved at $121{ }^{\circ} \mathrm{C}$ for $15 \mathrm{~min}$ and after $20 \mathrm{~mL} / \mathrm{L}$ of filtered ethanol $95 \%(v / v)$ was added aseptically to the ACB medium. A total of $0.2 \mathrm{~mL}$ of cycloheximide hydroalcoholic solution at $25 \% \mathrm{~m} / v$ was added directly to petri dishes.

Plates were incubated at $+28^{\circ} \mathrm{C}$ for $72-120 \mathrm{~h}$. Colonies were picked up from a suitable dilution of each sample on GYC and ACB agar media, grown for $3-5$ days at $+28{ }^{\circ} \mathrm{C}$ and purified through subculturing and plating. Pure kombucha isolates were named and strains were cultivated on the corresponding isolation medium for $3-5$ days at $+28^{\circ} \mathrm{C}$ [18] Long-term preservation methods of the strains were performed according to the standard procedures of the Microbial Resource Research Infrastructure-Italian Joint Research Unit (MIRRI-IT) [19]. Specifically, a seed lot of the strains was stored at $-80^{\circ} \mathrm{C}$, adding glycerol $50 \%(v / v)$ to the liquid media. The strains with significant cellulose production were deposited in the University of Modena and Reggio Emilia (UNIMORE) Microbial Culture Collection (UMCC, www.umcc.unimore.it, accessed on 3 February 2020).

\subsection{Phenotypic Characterization}

Strains were phenotypically characterized by determination of cell morphology, gram staining, catalase activity, potassium hydroxide $(\mathrm{KOH})$ test, consumption of calcium carbonate and oxidation of ethanol and acetic acid on $\mathrm{ACB}$ agar medium, as previously reported in Gullo et al. [20].

The $\mathrm{BC}$ production test was carried out by collecting the pellicles and boiling them in $4 \mathrm{~mL}$ of $5.0 \% \mathrm{NaOH}$ solution for $2 \mathrm{~h}$. Cellulose was confirmed when the pellicle did not dissolve after boiling [21]. DSMZ (German Collection of Microorganisms and Cell Cultures $\mathrm{GmbH}$ ) strains K. xylinus (DSMZ 2004) and G. oxydans (DSMZ 3503) were used as positive and negative controls, respectively. Tests were conducted in triplicate.

The amount of $\mathrm{BC}$ was estimated, as reported by Gullo et al. [22]. Briefly, pellicles were washed with distilled water and then treated with $1 \% \mathrm{NaOH}$ at $90{ }^{\circ} \mathrm{C}$ for $30 \mathrm{~min}$. Treated $\mathrm{BC}$ was washed twice with distilled water, the $\mathrm{pH}$ of the residual water was determined; the washing step was repeated until reaching neutral $\mathrm{pH}$. Drying was conducted at $80^{\circ} \mathrm{C}$. BC weight was measured by analytical balance (Gibertini E42S) [23]. The yield of BC produced was expressed in grams of dried BC per liter of broth.

\subsection{Genomic DNA Extraction, RFLP and Amplification of (GTG) $5 /$ REP-PCR and ERIC Elements}

Genomic DNA extraction was performed on liquid cultures, which were previously incubated for $72 \mathrm{~h}$ at $+28{ }^{\circ} \mathrm{C}$. Flasks were vigorously shaken to remove the embedded cells from $\mathrm{BC}$, the liquid medium was transferred to a sterile tube and centrifuged at $12,000 \times g$ for $5 \mathrm{~min}$. gDNA was extracted using the method previously proposed by Gullo et al. [24]. gDNA was checked by 3\% gel agarose in 1X TBE buffer and quantified by spectrophotometric measure (NanoDrop ND-1000). Band sizes were determined using a 100 bp DNA ladder (Invitrogen, Carlsbad, CA, USA).

RFLP analysis on the full-length 16S rRNA gene was performed using RsaI and $A l u \mathrm{I}$ endonucleases (Fermentas, Hanover, ND, USA), incubating at $+37^{\circ} \mathrm{C}$ for $2 \mathrm{~h}$. The restriction reaction was stopped by incubation at $80^{\circ} \mathrm{C}$ for $20 \mathrm{~min}$. The fragments were checked on $3 \%$ gel agarose in 1 X TBE buffer and sizes were determined using $100 \mathrm{bp}$ DNA ladder (Invitrogen). 
$(\mathrm{GTG})_{5}$ rep-PCR fingerprinting was carried out according to the method of Versalovic et al. [25], with some minor modifications. Isolates were subjected to REP-PCR with a single oligonucleotide GTG 5 (5'- GTGGTGGTGGTGGTG- $\left.3^{\prime}\right)$. Samples were incubated for 5 min at $94^{\circ} \mathrm{C}$ and then cycled 35 times at $94^{\circ} \mathrm{C}$ for $30 \mathrm{~s}, 40^{\circ} \mathrm{C}$ for $1 \mathrm{~min}$, and $72{ }^{\circ} \mathrm{C}$ for $4 \mathrm{~min}$. The samples were incubated for $7 \mathrm{~min}$ at $72{ }^{\circ} \mathrm{C}$ for final extension and kept at $4{ }^{\circ} \mathrm{C}$. ERIC elements were initially amplified according to Versalovic et al. [26] using the primers ERIC $1 \mathrm{R}$ (5'-ATGTAAGCTCCTGGGGATTCAC-3') and ERIC 2 (5'-AAGTAAGTGGGGTGAGCG-3'). Samples were incubated for $5 \mathrm{~min}$ at $94{ }^{\circ} \mathrm{C}$ and then cycled 30 times at $94{ }^{\circ} \mathrm{C}$ for $30 \mathrm{~s}, 57^{\circ} \mathrm{C}$ for $30 \mathrm{~s}$, and $65^{\circ} \mathrm{C}$ for $4 \mathrm{~min}$. The final extension was performed at $65^{\circ} \mathrm{C}$ at $8 \mathrm{~min}$ and kept at $4{ }^{\circ} \mathrm{C}$ until tested. The reproducibility of ERIC/PCR was also tested by amplifying gDNA from randomly chosen strains several times. For both rep-PCR, pattern band lengths were determined by comparison against a 100 bp plus DNA ladder for the smallest bands and by $1 \mathrm{Kbp}$ DNA ladder for the largest bands (Takara Bio, Inc., Otsu, Shiga, Japan).

\subsection{Statistics and Clustering Analysis of (GTG) 5 and ERIC Rep-PCR Patterns}

Patterns obtained from (GTG) 5 and ERIC rep-PCR runs were imported into BioNumerics tool, package version 8 . The cluster analysis was performed calculating Dice coefficients using a tolerance of $1 \%$ and optimization of $1 \%$. Clustering based on Dice coefficients was performed using the unpaired group method with arithmetic average (UPGMA) method. For each fingerprint assay, the cluster cut-off analysis was applied to define the most reliable clusters. The cophenetic correlation index was used as a statistical tool to evaluate the quality of branches. For each of the genotyping experiments, the discriminatory index (D), expressed as the probability that two strains consecutively taken from a sample would be placed into different clades, was calculated as described by Hunter and Gaston [27].

Correlation analysis was performed considering the most abundant clades (Clade 5, 6 and 7), in order to obtain statistically significant results. The Spearman correlation index was calculated using the Hmisc v4.4-2 R package [28] implemented in R v 4.0.3 [29]. The correlation plot was obtained using the Corrplot v 0.84 package [30].

\section{Results}

\subsection{Kombucha Characteristics and Isolated Strains}

Within 3 days of cultivation in $600 \mathrm{~mL}$ beakers, the two kombucha tea samples, GTK and BTK, demonstrated a thin exopolysaccharide layer that became thicker with time (from 2-3 $\mathrm{mm}$ to $10 \mathrm{~mm}$ at the end of the cultivation period). Optical microscopy observations showed a high number of free bacterial and yeast cells, as well as aggregates of cells within the matrix, making cell counting uncertain and not enlightening even from the first day of fermentation.

Titratable acidity reached a maximum of $12 \mathrm{~g} / \mathrm{L}$ at the end of fermentation in the black kombucha trial (GTK) and $6 \mathrm{~g} / \mathrm{L}$ in the green one (BTK). $\mathrm{pH}$ dropped from approximately 3.7 to 2.75 for both samples, as a result of acid formation. Although no inhibition compounds were determined in this study, the difference in the final amount of acetic acid of the GTK and BTK samples could be due to the occurrence of more antibacterial compounds in GTK [31]. Ethanol was nearly 0 at the beginning of the cultivation time and reached $0.28 \%(v / v)$ and $0.30 \%(v / v)$ at the final time, for samples GTK and BTK, respectively. The low value of observed ethanol is in agreement with the gradual increase in acetic acid during cultivation time.

The isolation was performed from preculture (P1 and P2) and samples at 0, 6, and 12 days of cultivation. A total of 122 isolates were selected based on the colony and/or cellular morphologies. Microscopically, presumptive acetic acid bacteria cells appeared in single or grouped pairs or short chains, Gram-negative, catalase-positive, and $\mathrm{KOH}$ positive. A total of 46 isolates, which oxidized both ethanol and acetic acid, as confirmed by the ethanol chalk-ethanol test on GYC and the colorimetric assay on ACB, and produced a well-defined cellulose layer and/or formed both a cellulose layer and cellulose particles dispersed in the surrounding liquid, were considered in this study (Table 1). 


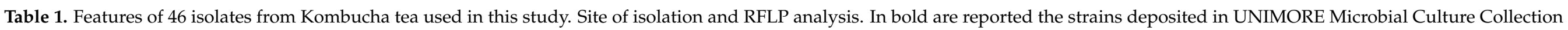
(UMCC) collection; within the brackets is the assigned accession number.

\begin{tabular}{|c|c|c|c|c|c|c|c|c|c|c|}
\hline * Strain & Sample & Time & BC $(g / L)$ & Colony Morphology & Liquid Growth & $A l u \mathrm{I}(\mathrm{pb})$ & Group & $R s a \mathrm{I}(\mathrm{bp})$ & Group & Reference \\
\hline K1A18 & liquid & 6 & $4.0448 \pm 0.0008$ & green cellulosic & cellulose layer & - & - & $120,400,425,550$ & $\mathrm{~A}$ & This study \\
\hline K1A34 & liquid & 12 & $5.6214 \pm 0.0010$ & $\begin{array}{l}\text { green with light } \\
\text { cellulosic edge }\end{array}$ & cellulose layer & $150,450,800$ & 1 & $120,400,425,550$ & A & This study \\
\hline K1A7 & liquid & 0 & $1.5886 \pm 0.0004$ & cellulosic & cellulose layer/deposit & $150,450,800$ & 1 & $120,400,425,550$ & $\mathrm{~A}$ & This study \\
\hline K1A8 & liquid & 0 & $2.5886 \pm 0.0002$ & cellulosic & cellulose layer & $150,450,800$ & 1 & $120,400,425,550$ & $\mathrm{~A}$ & This study \\
\hline K1A9 & liquid & 0 & $3.4014 \pm 0.0004$ & green cellulosic & cellulose layer & - & - & - & - & This study \\
\hline $\begin{array}{c}\text { K1G2 } \\
(=\mathrm{UMCC} 2964)\end{array}$ & liquid & P1 & $4.7895 \pm 0.0014$ & white cellulosic edge & cellulose layer/deposit & $150,450,800$ & 1 & $120,400,425,550$ & A & [20] \\
\hline $\mathrm{K} 1 \mathrm{G} 22$ & liquid & 12 & $0.7057 \pm 0.0003$ & cellulose light & cellulose layer/deposit & $150,450,800$ & 1 & $120,400,425,550$ & $\mathrm{~A}$ & [20] \\
\hline K1G23 & liquid & 12 & $4.8122 \pm 0.0003$ & dark cellulose & cellulose layer & $150,450,800$ & 1 & $120,400,425,550$ & $\mathrm{~A}$ & [20] \\
\hline K1G24 & liquid & 12 & $4.1210 \pm 0.0001$ & white cellulose & only cellulose deposit & - & - & $120,400,425,550$ & $\mathrm{~A}$ & [20] \\
\hline K1G3 & liquid & P1 & $2.1857 \pm 0.0052$ & light beige & cellulose layer & $150,450,800$ & 1 & $120,400,425,550$ & $\mathrm{~A}$ & [20] \\
\hline K1G4 & liquid & 0 & $1.1738 \pm 0.0032$ & cellulosic & cellulose layer/deposit & $150,450,800$ & 1 & $120,400,425,550$ & $\mathrm{~A}$ & [20] \\
\hline K1G5 & liquid & 0 & $4.9590 \pm 0.0027$ & cellulosic & cellulose layer/deposit & $150,450,800$ & 1 & $120,400,425,550$ & $\mathrm{~A}$ & [20] \\
\hline K1G6 & liquid & 0 & $5.3676 \pm 0.0025$ & white cellulosic & cellulose layer/deposit & $150,450,800$ & 1 & $120,400,425,550$ & $\mathrm{~A}$ & [20] \\
\hline $\begin{array}{c}\text { K2A10 } \\
(=\mathrm{UMCC} 2965)\end{array}$ & liquid & 0 & $5.0405 \pm 0.0008$ & cellulosic green small & cellulose layer & $150,450,800$ & 1 & $120,400,425,550$ & A & This study \\
\hline K2A33 & liquid & 6 & $0.6414 \pm 0.0005$ & green cellulosic & cellulose layer & $150,450,800$ & 1 & $120,400,425,550$ & $\mathrm{~A}$ & This study \\
\hline K2A44 & liquid & 12 & $5.1971 \pm 0.0002$ & small green & cellulose layer/deposit & $150,450,800$ & 1 & $120,400,425,550$ & $\mathrm{~A}$ & This study \\
\hline K2A45 & pellicle & 12 & $5.2133 \pm 0.0004$ & light edge & cellulose layer & $150,450,800$ & 1 & $120,400,425,550$ & $\mathrm{~A}$ & This study \\
\hline K2A46 & liquid & 12 & $5.7833 \pm 0.0001$ & dark center light edge & cellulose layer & $150,450,800$ & 1 & $120,400,425,550$ & $\mathrm{~A}$ & This study \\
\hline $\mathrm{K} 2 \mathrm{~A} 47$ & pellicle & 12 & $5.8019 \pm 0.0001$ & blue medium displayed & cellulose layer & $150,450,800$ & 1 & $120,400,425,550$ & $\mathrm{~A}$ & This study \\
\hline K2A7 & liquid & 0 & $4.6076 \pm 0.0007$ & green cellulosic small & cellulose layer & $150,450,800$ & 1 & $400,450,550$ & B & This study \\
\hline $\mathrm{K} 2 \mathrm{~A} 8$ & liquid & 0 & $4.4781 \pm 0.0004$ & green cellulosic small & cellulose layer & - & - & - & - & This study \\
\hline $\mathrm{K} 2 \mathrm{G} 1$ & liquid & P2 & $6.8843 \pm 0.0004$ & cellulosic & cellulose layer/deposit & $150,450,800$ & 1 & $120,400,425,550$ & $\mathrm{~A}$ & This study \\
\hline K2G10 & liquid & 0 & $4.9752 \pm 0.0016$ & cellulosic small & cellulose layer/deposit & $150,450,800$ & 1 & $400,450,550$ & $\mathrm{~B}$ & [20] \\
\hline K2G11 & liquid & 0 & $1.0638 \pm 0.0003$ & white cellulosic & cellulose layer/deposit & $150,450,800$ & 1 & $120,400,425,550$ & $\mathrm{~A}$ & [20] \\
\hline K2G12 & liquid & 0 & $6.2805 \pm 0.0001$ & small cellulosic & cellulose layer/deposit & $150,450,800$ & 1 & $120,400,425,550$ & $\mathrm{~A}$ & [20] \\
\hline K2G14 & liquid & 0 & $7.7414 \pm 0.0005$ & white cellulosic & cellulose layer/deposit & $150,450,800$ & 1 & $120,400,425,550$ & $\mathrm{~A}$ & [20] \\
\hline K2G15 & liquid & 0 & $7.5448 \pm 0.0001$ & creamy & cellulose layer/deposit & $150,450,800$ & 1 & $400,450,550$ & A & [20] \\
\hline K2G2 & pellicle & P2 & $6.2548 \pm 0.0004$ & & cellulose layer/deposit & $150,450,800$ & 1 & $120,400,425,550$ & $\mathrm{~A}$ & [20] \\
\hline
\end{tabular}


Table 1. Cont.

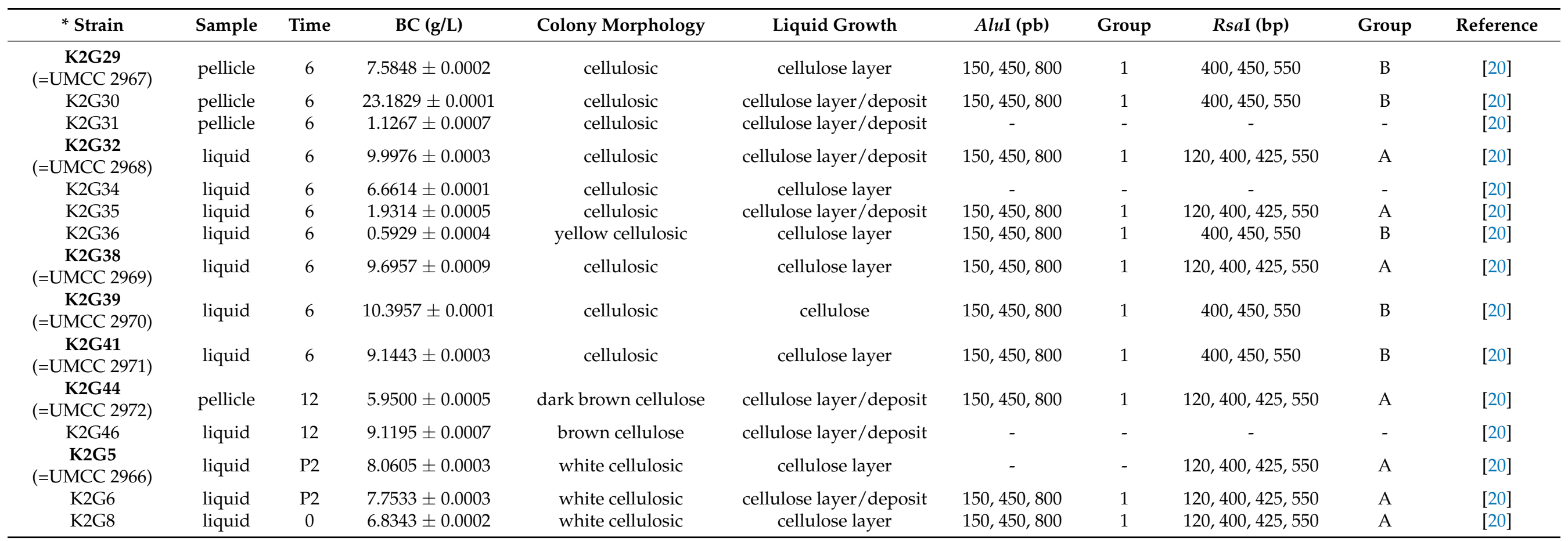

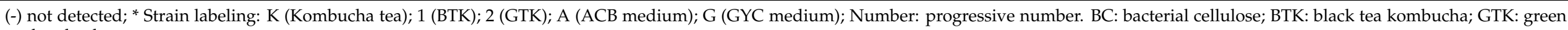
tea kombucha. 
Qualitative cellulose tests confirmed their ability to produce BC. Significant macroscopic diversity in the cellulosic material was observed, coupled with high variability in terms of amount of BC, as reported in Figure 1. The strains with a BC production level of at least higher than $4 \mathrm{~g} / \mathrm{L}$ were deposited in the UMCC culture collection with the code reported in Table 1.

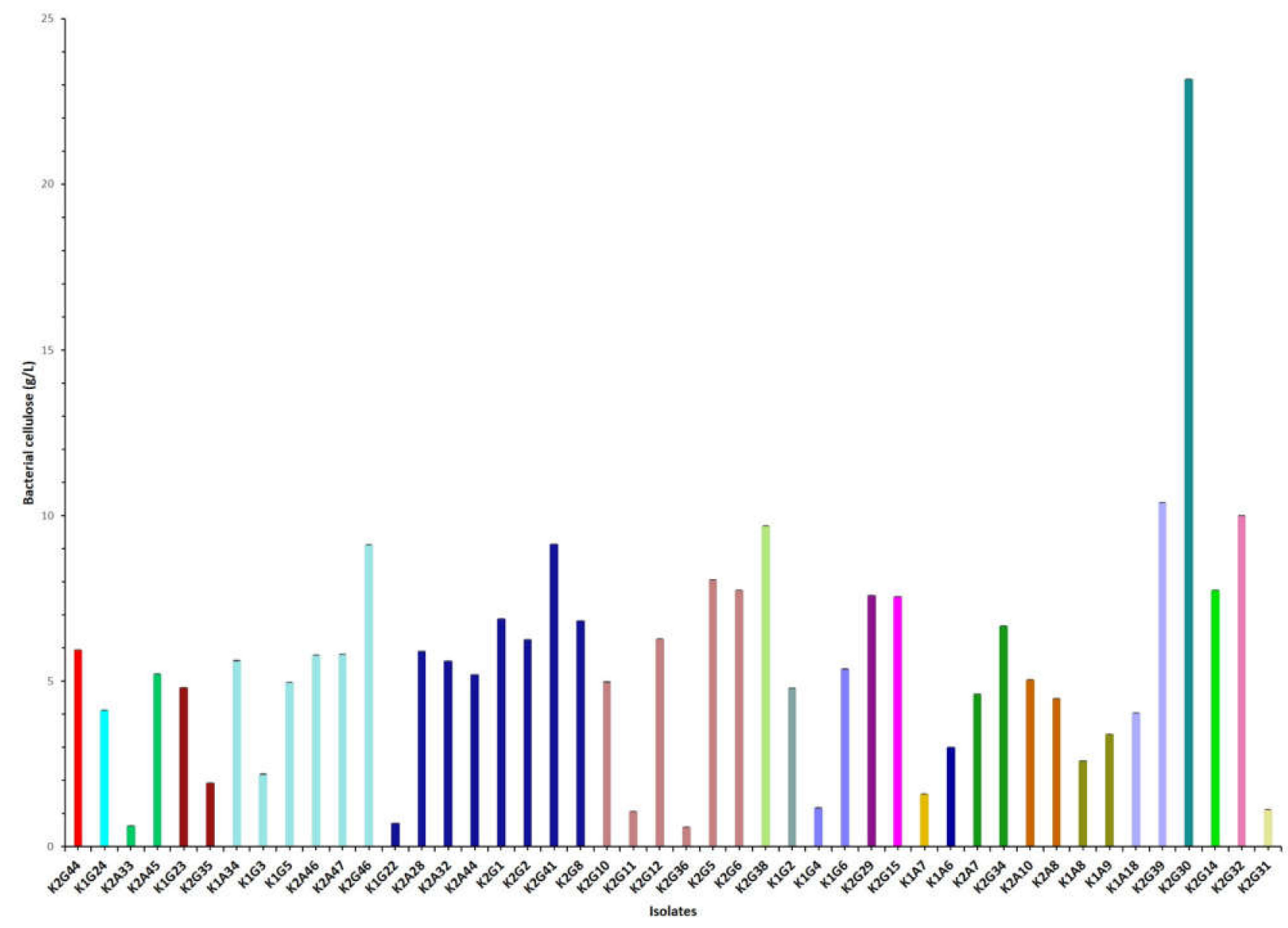

Figure 1. Bacterial cellulose yields of selected strains isolated from Kombucha tea. Each value is the mean of three parallel replicates \pm standard deviation.

\subsection{Diversity of Acetic Acid Bacteria from Kombucha Tea}

The RFLP analysis on 16S rRNA, using RsaI and AluI restriction endonucleases, was conducted as a preliminary test to investigate the diversity of isolates recovered from kombucha tea samples. The mapping analysis based on the size of the fragments obtained by RsaI and AluI showed high homogeneous results, indicating the isolates as members of the same species. This evidence was in agreement with a previous study [16] which grouped Komagataeibacter strains according to RsaI and $A l u \mathrm{I}$ restriction enzymes and observed similarities between the pattern of K. xylinus DSMZ 2004 with the Komagataeibacter strains investigated in this study. The low variability of the fingerprinting pattern is also consistent with previous studies on the high similarity of the 16S rRNA gene among the Komagataeibacter genus and especially within the K. xylinus species [32,33].

From the genotyping of strains performed by using (GTG) $)_{5}$ and ERIC fingerprinting techniques, two dendrograms were generated (Figure 2). Based on the cluster cut-off analysis, profiles obtained using the amplification of interspersed tandem repeats GTG (Figure 2) were capable of discriminating between the strains considering a minimum percentage of similarity of $27.9 \%$. A total of five major clades were created with a discrimination power of 0.42 , calculated using the D index (Simpson index) [27]. In order to 
improve the discrimination power of the analysis, we considered a minimum percentage of similarity of $70 \%$. At this percentage of similarity, the resulted discrimination power was 0.94, defining 20 different biotypes. Among the detected clades, eight of them included just one isolate while seven were formed by two isolates. It was possible to distinguish two major clades, of which, one included nine isolates (clade 18) and another included five isolates (clade 19). The two reference strains, represented by K1G4 (=UMCC 2947) and K2G30 (=UMCC 2756) clustered into two different clades, represented by clades 19 and 7, respectively. The similarity percentage among the two references was $40.2 \%$.

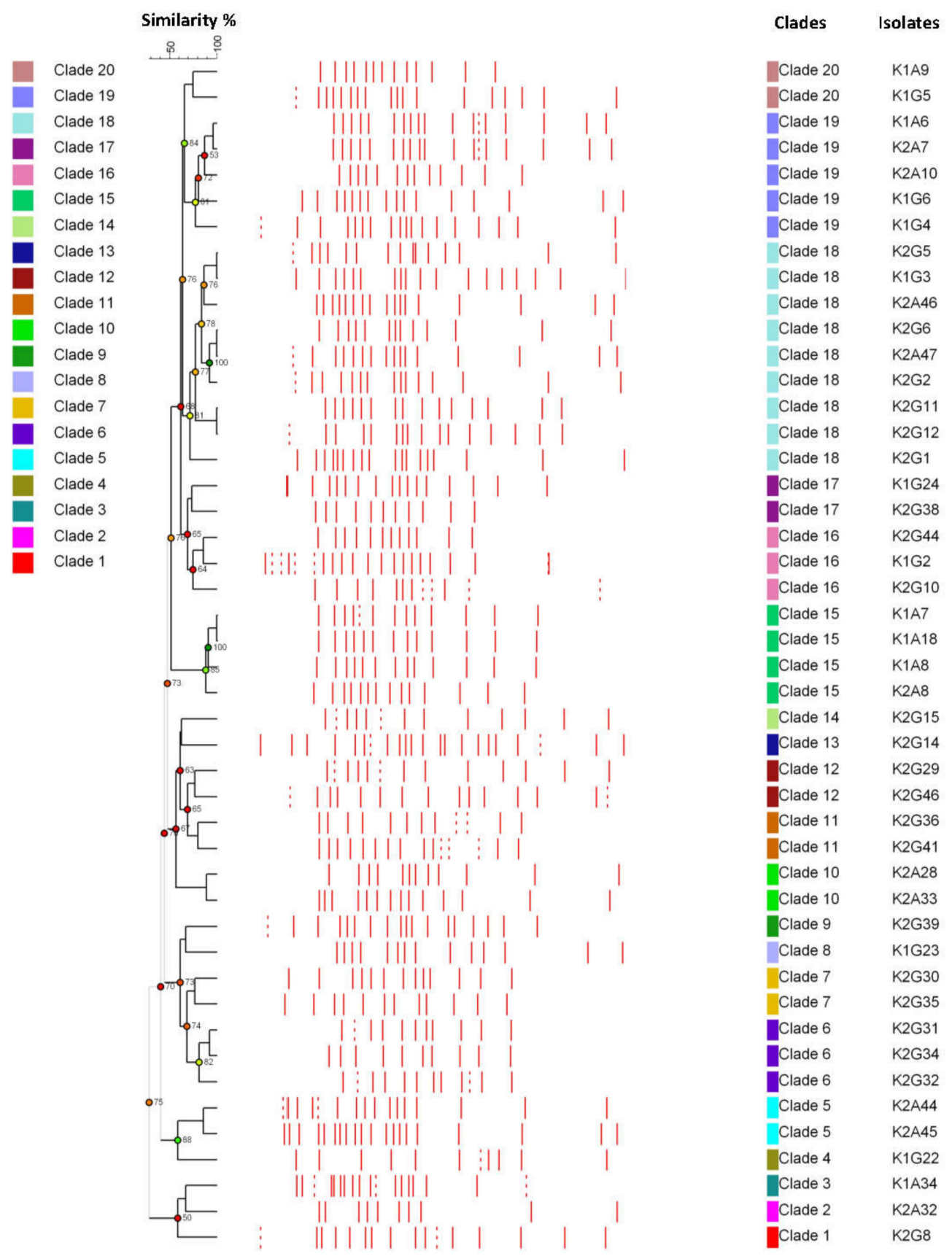

Figure 2. Dendrograms obtained from UPGMA analysis, using Dice's coefficient, of the digitized patterns obtained from $(\mathrm{GTG})_{5}$ rep-PCR. The similarity threshold for biotypes discrimination was $70 \%$. The cophenetic coefficient is represented by numbers and dots colored as red-orange-yellow-green, based on the branch quality.

The phylogenetic tree obtained from the digitized pattern profile using ERIC repPCR is represented in Figure 3. Based on the clustering cut-off analysis, ERIC was able 
to discriminate using a minimum similarity percentage of $40 \%$, identifying five major clades, as in the case of $(\mathrm{GTG})_{5}$. The clustering cut-off analysis discriminated a total of 19 biotypes, with a discrimination power of 0.95 , slightly higher compared to (GTG) $)_{5}$. A total of six clades were represented by just one isolate, while the remaining isolates were well distributed among the detected clades. Three clades were represented by five isolates (clade 7, 16, and 17) and two clusters by four isolates (clade 8 and 9). The remaining clades were represented by three and two isolates. The number of detected clades was not so different compared to (GTG) 5 and, also in this case, the reference strains (K1G4 and K2G30) were found to be separated into two different groups (clade 15 for K1G4 and clade 12 for K2G30). The similarity of Dice indexes based on the patterns obtained from ERIC rep-PCR was $56.7 \%$; quite similar to that obtained using (GTG) 5 rep-PCR $(40.2 \%)$.
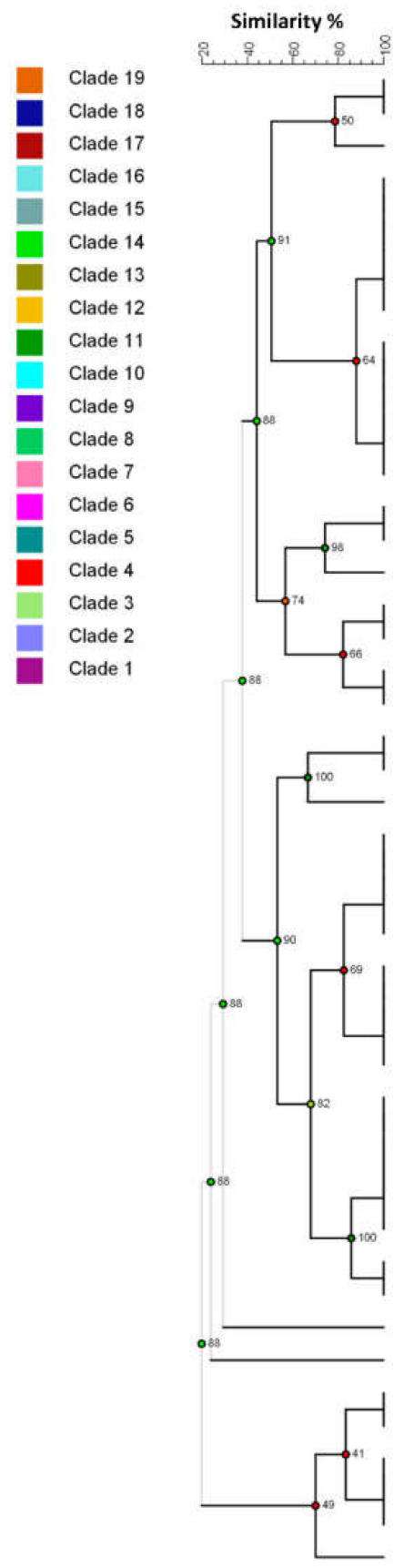

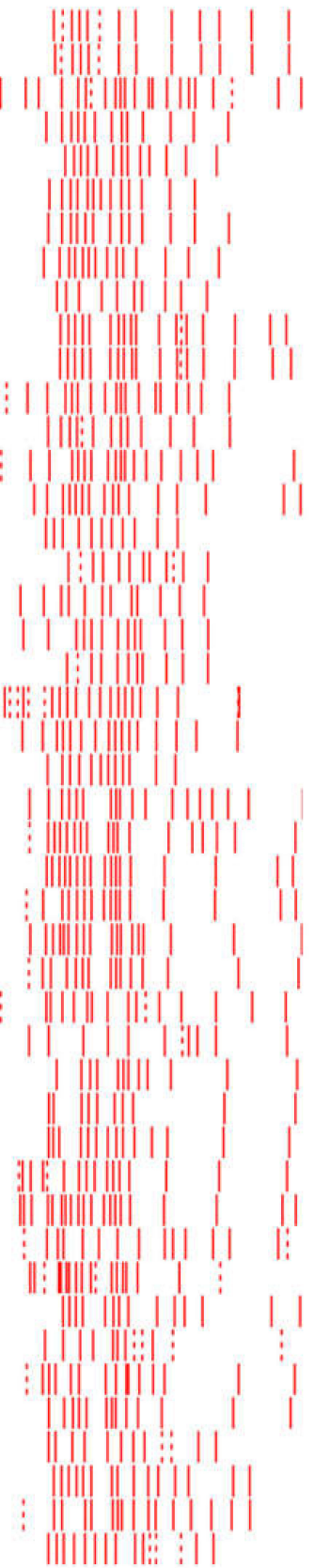

\begin{tabular}{|c|c|}
\hline Clades & Isolate \\
\hline Clade 19 & K2G15 \\
\hline Clade 19 & $\mathrm{~K} 2 \mathrm{G} 29$ \\
\hline Clade 18 & $\mathrm{~K} 2 \mathrm{G} 14$ \\
\hline Clade 17 & K1A8 \\
\hline Clade 17 & $\mathrm{~K} 2 \mathrm{~A} 10$ \\
\hline Clade 17 & K1A9 \\
\hline Clade 17 & $\mathrm{~K} 1 \mathrm{~A} 18$ \\
\hline Clade 17 & $K 2 A 8$ \\
\hline Clade 16 & K2G34 \\
\hline Clade 16 & $\mathrm{~K} 1 \mathrm{~A} 6$ \\
\hline Clade 16 & $\mathrm{~K} 2 \mathrm{~A} 7$ \\
\hline Clade 16 & K2G39 \\
\hline Clade 16 & K1A7 \\
\hline Clade 15 & K1G4 \\
\hline Clade 15 & K1G6 \\
\hline Clade 14 & K2G38 \\
\hline Clade 13 & $\mathrm{~K} 2 \mathrm{G} 32$ \\
\hline Clade 13 & K2G35 \\
\hline Clade 12 & $\mathrm{~K} 2 \mathrm{G} 30$ \\
\hline Clade 12 & $\mathrm{~K} 2 \mathrm{G} 31$ \\
\hline Clade 11 & $\mathrm{~K} 1 \mathrm{G} 2$ \\
\hline Clade 11 & K1G24 \\
\hline Clade 10 & K2G44 \\
\hline Clade 9 & $\mathrm{~K} 1 \mathrm{G} 3$ \\
\hline Clade 9 & K1G5 \\
\hline Clade 9 & $\mathrm{~K} 2 \mathrm{~A} 46$ \\
\hline Clade 9 & $\mathrm{~K} 2 \mathrm{~A} 47$ \\
\hline Clade 8 & $\mathrm{~K} 2 \mathrm{G} 1$ \\
\hline Clade 8 & $\mathrm{~K} 2 \mathrm{G} 2$ \\
\hline Clade 8 & $\mathrm{~K} 2 \mathrm{G} 8$ \\
\hline Clade 8 & $\mathrm{~K} 1 \mathrm{G} 22$ \\
\hline Clade 7 & $\mathrm{~K} 2 \mathrm{~A} 28$ \\
\hline Clade 7 & $\mathrm{~K} 2 \mathrm{~A} 32$ \\
\hline Clade 7 & $\mathrm{~K} 2 \mathrm{~A} 33$ \\
\hline Clade 7 & K2A44 \\
\hline Clade 7 & K2A45 \\
\hline Clade 6 & $\mathrm{~K} 2 \mathrm{G} 46$ \\
\hline Clade 6 & $\mathrm{~K} 1 \mathrm{~A} 34$ \\
\hline Clade 5 & K1G23 \\
\hline Clade 4 & K2G10 \\
\hline Clade 3 & K2G5 \\
\hline Clade 3 & K2G6 \\
\hline Clade 2 & K2G36 \\
\hline Clade 2 & K2G11 \\
\hline Clade 2 & $\mathrm{~K} 2 \mathrm{G} 12$ \\
\hline Clade 1 & K2G41 \\
\hline
\end{tabular}

Figure 3. Dendrograms obtained from UPGMA analysis, using Dice's coefficient, of the digitized patterns obtained from ERIC rep-PCR. The similarity threshold for biotypes discrimination was $70 \%$. The cophenetic coefficient is represented by numbers and dots colored as red-orange-yellow-green, based on the branch quality. 


\subsection{Improving the Fingerprinting of Komagataeibacter Strains}

In order to improve the sensitivity of the intraspecific discrimination, the data obtained from both rep-PCR assays were combined. The clustering analysis is reported in Figure 4. Based on the cluster cut-off analysis, the combination of (GTG) $)_{5}$ and ERIC rep-PCR allowed for discriminating the isolates, grouping them into 22 clades, considering a similarity percentage threshold of $94 \%$. The discrimination power, calculated as the Simpson index, was 0.94 , mining a high intraspecies diversity. Most of the isolates were grouped into three clusters (clade 5,6 , and 7$)$ representing $43.5 \%$ of the isolates $(n=20)$. The remaining isolates $(n=26)$ were dispersed in 19 clades, of which, most of them consisted of just one isolate $(n=12)$. The reference strains were clustered into two different clades, as observed in both the case of (GTG) 5 and ERIC rep-PCR. Clade 10, in which K1G4 was clustered with K1G6, and clade 19, where K2G30 clustered alone, had a similarity percentage of Dice index of $84.9 \%$, higher considering the separated results from (GTG) 5 and ERIC rep-PCR. This result is in agreement with the meaning of the combined analysis, since the two reference strains belong to the species of K. xylinus, as previously stated [14,34].

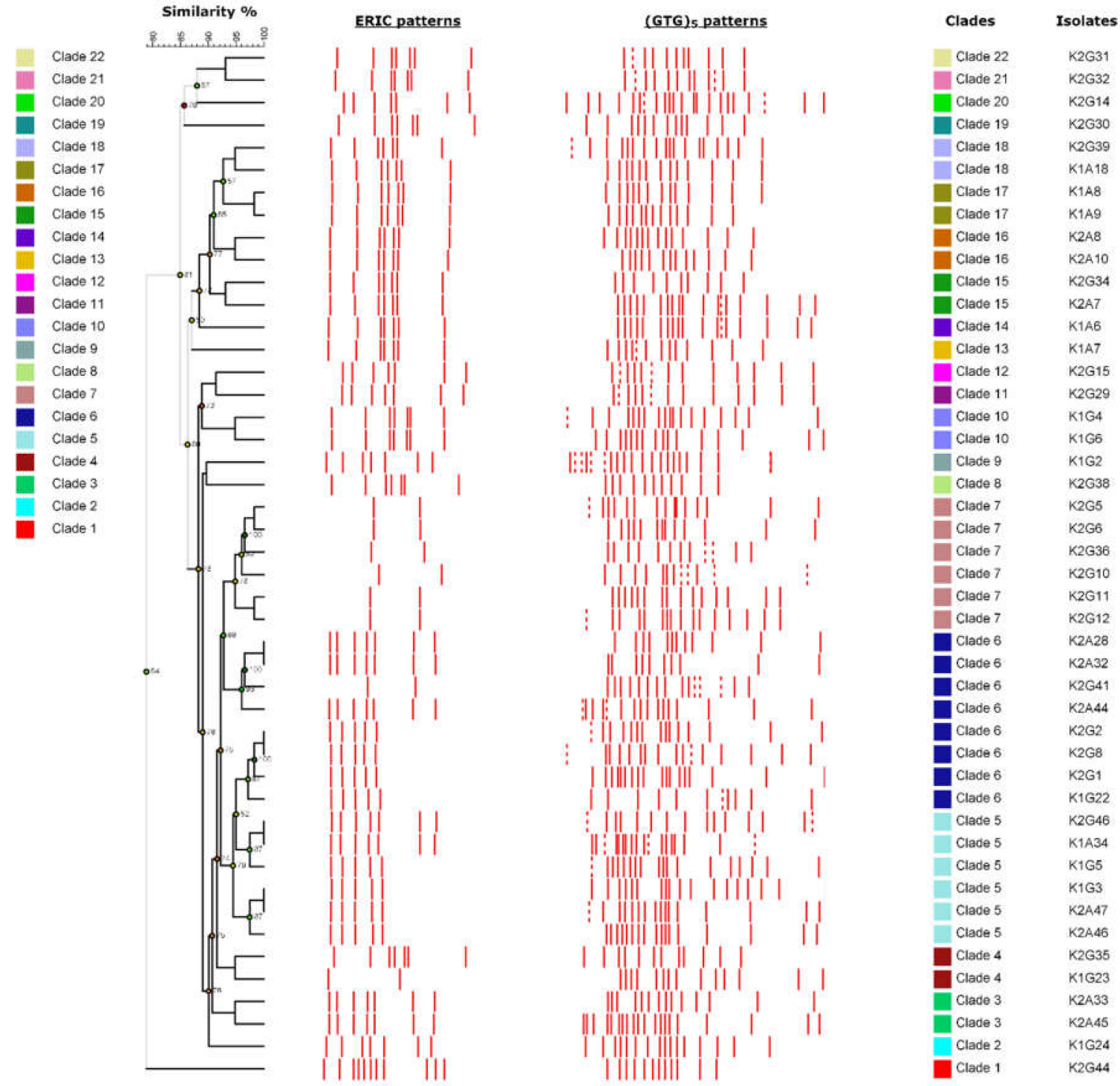

Figure 4. Dendrogram obtained combining the digitalized patterns from both (GTG)5 rep-PCR and ERIC rep-PCR. The dendrogram was drawn from UPGMA analysis using Dice's coefficient. The discrimination of biotypes was performed considering a similarity threshold of $94 \%$. The cophenetic coefficient is represented by numbers and dots colored as red-orange-yellow-green, based on the branch quality. Cluster colors were defined in agreement with the Figure 1. 


\subsection{Correlation between Strains and Cellulose Yield}

In order to understand putative correlation of the BC yield obtained from isolates with time and environmental factors, such as sampling fraction (pellicle or liquid) and clustering methods applied in this study, a Spearman correlation index was calculated. At the beginning all clades that resulted from the combined fingerprinting approach (Figure 4) were compared with all variables (Figure 5a). All factors seemed to strongly influence the $\mathrm{BC}$ yields. Only the time of sampling seemed to slightly influence BC production, but with a low value $(R 2=-0.38, p=0.009)$. In order to understand how the sampling time could affect BC yield, the three most abundant clades, represented by clade 5, 6 and 7 were evaluated by calculating the Spearman coefficient, considering both time and sampling fraction. Regarding clade $5(n=6)$ (Figure $5 b)$, the time seems to correlate positively $(\mathrm{R} 2=0.84, p=0.03$ ). Indeed, the amount of $\mathrm{BC}$ (Figure 1$)$ was higher for isolates sampled at day 12 (K2A46, K2A47, K2G46 and K1A34) and lower for isolates sampled at day 0 and from the preculture (K1G5 and K1G3 respectively). In clade $6(n=8)$ (Figure 5c), BC yield seems to be not statistically correlated by the sampling time ( $22=-0.70, p>0.05$ ). Regarding clade $7(n=6)$ (Figure $5 \mathrm{~d})$, the sampling time negatively affects the $\mathrm{BC}$ amount $(\mathrm{R} 2=-0.92, p=0.009)$.

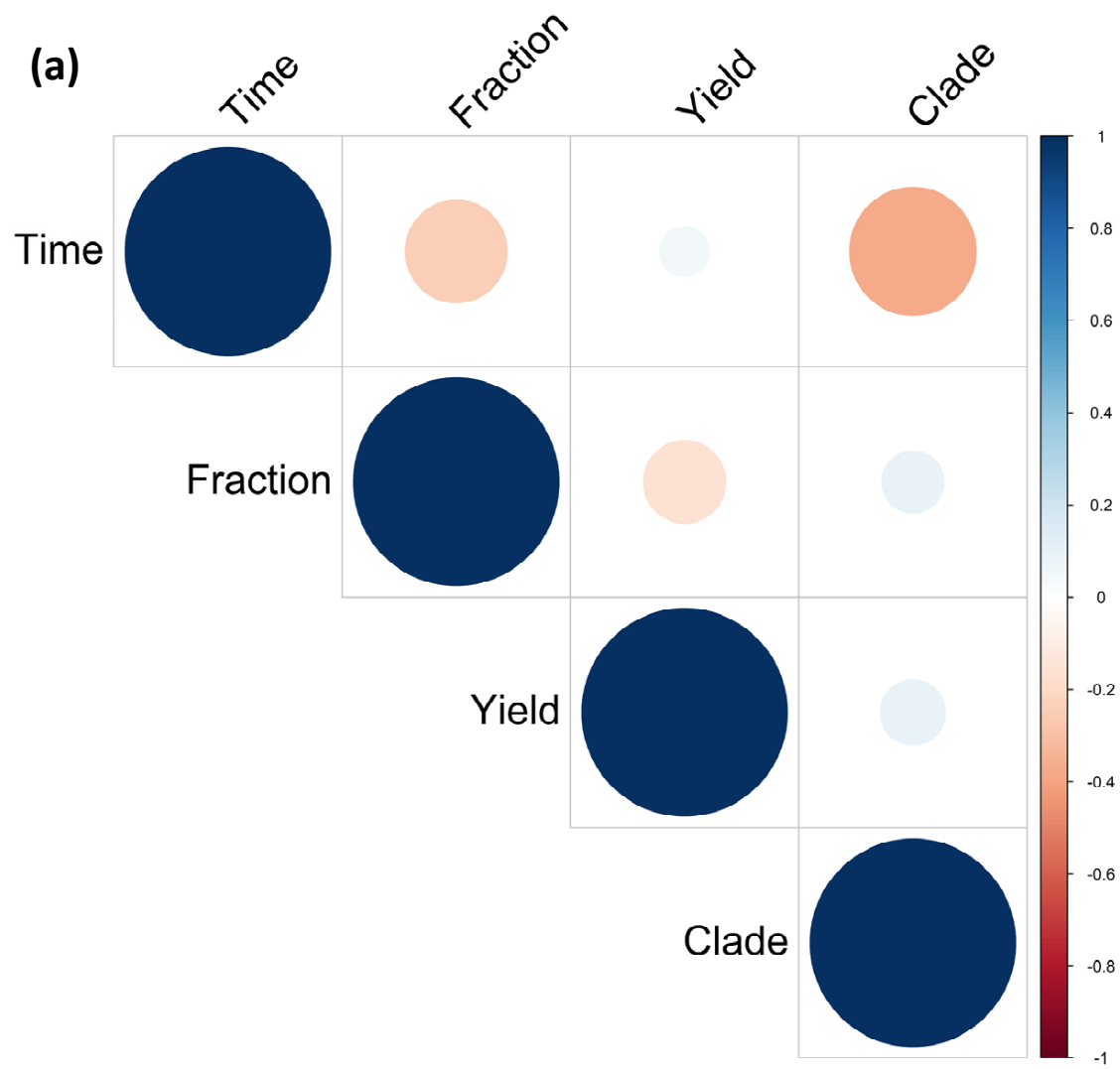

(b)

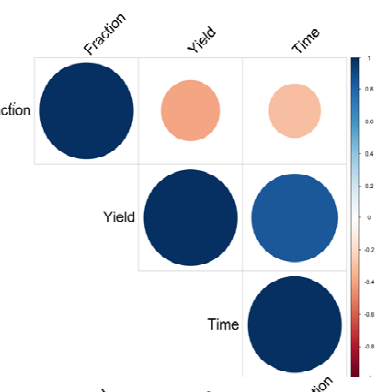

(c)

(d)
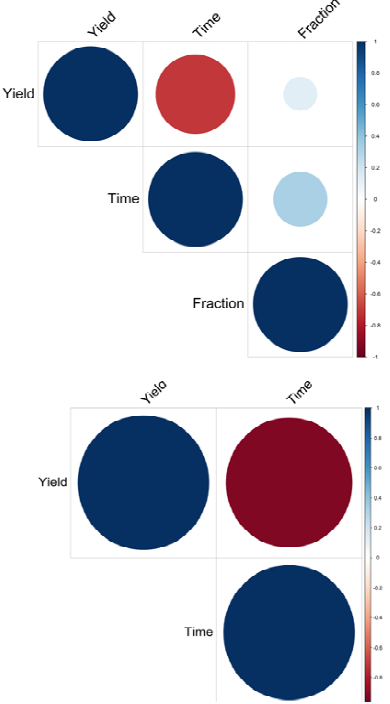

Figure 5. Correlation plot of the most abundant clades. Spearman correlation among time, environmental variables and obtained yields. (a) All retrieved clades were compared with time and environmental variables. Yield obtained within (b) clade 5, (c) clade 6 were compared with time and fraction variables. For clade 7 (d), includes only isolates sampled from liquid fraction.

\section{Discussion}

Bacterial cellulose is receiving a great deal of attention due to several features that make it suitable for many biotechnological applications, such as biomedical devices, food packaging components and engineering materials $[1,2,35]$. 
It is well known from the literature that kombucha tea represents one of the most abundant reservoirs of BC producer bacteria, in particular, strains belonging to the Komagataeibacter genus $[10,12]$.

In this study, kombucha tea was chosen as a selective source for recovering cellulose producing bacteria. A total of 46 isolates were selected as the main components of the liquid and pellicle fractions of GTK and BTK kombucha tea samples and their phenotypic and genotypic variability was evaluated. RFLP of $16 \mathrm{~S}$ rRNA gene and an analysis of the interspecific variability of isolates was conducted, and the results were discussed, considering the available genome sequences of strains K1G4 and K2G30.

The data obtained by RFLP analysis showed a very low variability in terms of the number of different species isolated from kombucha tea. This result is in agreement with previous studies reflecting both the low species diversity in kombucha tea [10], as well as the difficulty of taxonomic assignment of Acetobacteraceae by using 16S rRNA gene, due to its similarity in high phylogenetic related organisms, as extensively reported in the literature [36].

Considering the analysis of the intraspecific variability within bacteria, usually, genotyping is performed using the amplification of highly conserved tandem repeat regions that are widely dispersed in the genome. The amplification of repeated elements of genomic DNA, such as (GTG) 5 and ERIC sequences, offers some advantages in terms of costs and rapidity, and is well developed for several Gram-negative and Gram-positive bacterial species, such as Lactobacilli [37] and Enterococci [38] and acetic acid bacteria [39].

In this study, the clustering analysis using the digitized patterns of (GTG) 5 elements revealed the clustering of the 46 isolates into five large clusters considering a cluster cut-off value of $50 \%$ in similarity. The discrimination power of this analysis was 0.94 considering a similarity threshold of $70 \%$. At this similarity value, a total of 20 different biotypes were detected. Similar results were obtained using the amplification of ERIC repeated elements. Considering the cluster cut-off analysis, the comparison of the digitized patterns of ERIC rep-PCR showed a clustering of the 46 isolates with a similarity percentage of $50 \%$, the same result obtained using $(\mathrm{GTG})_{5}$ rep-PCR. The discrimination power of ERIC fingerprint was 0.95 , very similar to the $(\mathrm{GTG})_{5}$ rep-PCR, considering a similarity percentage of 70 . Based on these results, a total of 19 different clades were identified, compared to the 20 obtained using $(\mathrm{GTG})_{5}$ rep-PCR. In both the fingerprint approaches, K1G4 and K2G30, previously identified as K. xylinus [14,34], were considered as reference strains and they were clustered into two different clades. Among the two reference strains, the percentage of similarity was $44.2 \%$ in the case of $(\mathrm{GTG})_{5}$ rep-PCR and $56.7 \%$ for ERIC rep-PCR. These results support the hypothesis that most of the strains analyzed belong to the K. xylinus species and that the discrimination was performed at the strain level.

In order to improve the genotyping analysis, a combined model of the two fingerprint assays was performed (Figure 3). The resulting analysis showed a clusterization of the isolates into seven clades based on the cluster cut-off value of $88 \%$ of pattern similarity. The discrimination power of this analysis was 0.94 at $94 \%$ of similarity. The number of biotypes defined by the combined model was 22; meaning that an improvement of the discrimination of the isolates was achieved compared to the single results obtained by the two approaches. Additionally, concerning the reference strains (K1G4 and K2G30) in this case, we observed a grouping into two different clades, with a similarity percentage of $84.9 \%$, meaning that all the isolates with equal or major than that value possibly belong to the species of K. xylinus. Based on this consideration, all of the isolates could be assigned to the K. xylinus except one isolate, the K2G44, clustering out of the group, with a similarity percentage of $78.8 \%$. The data were in agreement with previous studies of the fingerprinting analysis of acetic acid bacteria $[39,40]$, in which the differences of strains among the same species (as Komagataeibacter xylinus) were about $80 \%$. In this case, combining the two methods, the detection of different strains was improved.

The correlation analysis deriving from the combined strain clustering allowed us to link the $\mathrm{BC}$ yield with isolation time and environmental variables. A possible explanation 
of the obtained results may lie in the genetic plasticity features of acetic acid bacteria. It is well known in the literature that acetic acid bacteria are able to adapt themselves to environmental stressors, such as temperature and high concentration of organic acids, by acquiring genetic material from the environment or losing it. Indeed, acetic acid bacteria possess a large number of transposons genes and plasmids [41]. One example is provided by Acetobacter species which strains adapt themselves to environmental conditions along cultivation and fermentation cycles [42,43]. In Komagataeibacter species the genetic plasticity has not yet been evaluated. However, we believe this aspect should be elucidated in the light to better understand the variability of BC yield within strains of Komagataeibacter genus.

The kombucha tea samples analyzed in this study allowed us to recover a pool of acetic acid bacteria strains, which have been characterized and deposited into the UMCC culture collection as promising candidates for BC production.

Author Contributions: M.G. conceptualized the research, provided resources and supervised the work; D.M. performed experiments; S.L.C. performed genotyping analysis and wrote part of the original draft; L.D.V. reviewed and edited the manuscript; K.A. wrote part of the original draft; M.B. participated in the investigation, reviewed and edited the manuscript. All authors have read and agreed to the published version of the manuscript.

Funding: Part of this research was granted by The Research Doctorate School in Food and Agricultural Science, Technology and Biotechnology (STEBA).

Institutional Review Board Statement: Not applicable.

Informed Consent Statement: Not applicable.

Acknowledgments: The National Institute of Applied Sciences and Technology (INSAT, Tunisia), is acknowledged for providing Kombucha samples. A special thanks to The Research Doctorate School in Food and Agricultural Science, Technology and Biotechnology (STEBA) is acknowledged for assigning the "Michela Stanca" award. The JRU MIRRI-IT is greatly acknowledged for technical and scientific support.

Conflicts of Interest: The authors declare no conflict of interest.

\section{References}

1. Robotti, F.; Bottan, S.; Fraschetti, F.; Mallone, A.; Pellegrini, G.; Lindenblatt, N.; Starck, C.; Falk, V.; Poulikakos, D.; Ferrari, A. A micron-scale surface topography design reducing cell adhesion to implanted materials. Sci. Rep. 2018. [CrossRef]

2. Haghighi, H.; Gullo, M.; La China, S.; Pfeifer, F.; Siesler, H.W.; Licciardello, F.; Pulvirenti, A. Characterization of bio-nanocomposite films based on gelatin/polyvinyl alcohol blend reinforced with bacterial cellulose nanowhiskers for food packaging applications. Food Hydrocoll. 2020, 106454. [CrossRef]

3. Barbi, S.; Taurino, C.; La China, S.; Anguluri, K.; Gullo, M.; Montorsi, M. Mechanical and structural properties of environmental green composites based on functionalized bacterial cellulose. Cellulose 2021, 1-7. [CrossRef]

4. Valera, M.J.; Torija, M.J.; Mas, A. Detrimental effects of acetic acid bacteria in foods. In Acetic Acid Bacteria: Fundamentals and Food Applications, 1st ed.; Sengun, I., Ed.; CRC Press: Boca Raton, FL, USA; Taylor \& Francis Group: Boca Raton, FL, USA, 2017; Volume 10, pp. 299-320.

5. Gullo, M.; La China, S.; Falcone, P.M.; Giudici, P. Biotechnological production of cellulose by acetic acid bacteria: Current state and perspectives. Appl. Microbiol. Biotechnol. 2018, 1-14. [CrossRef] [PubMed]

6. Son, H.J.; Heo, M.S.; Kim, Y.G.; Lee, S.J. Optimization of fermentation conditions for the production of bacterial cellulose by a newly isolated Acetobacter sp. A9 in shaking cultures. Biotechnol. Appl. Biochem. 2001, 33, 1. [CrossRef] [PubMed]

7. La China, S.; Zanichelli, G.; De Vero, L.; Gullo, M. Oxidative fermentations and exopolysaccharides production by acetic acid bacteria: A mini review. Biotechnol. Lett. 2018, 40, 1289-1302. [CrossRef]

8. Coton, M.; Pawtowski, A.; Taminiau, B.; Burgaud, G.; Deniel, F.; Coulloumme-Labarthe, L.; Fall, A.; Daube, G.; Coton, E. Unraveling microbial ecology of industrial-scale Kombucha fermentations by metabarcoding and culture-based methods. FEMS Microbiol. Ecol. 2017, 93. [CrossRef]

9. Laureys, D.; Britton, S.J.; De Clippeleer, J. Kombucha tea fermentation: A review. J. Am. Soc. Brew. Chem. 2020, 78, 165-174. [CrossRef]

10. Sievers, M.; Lanini, C.; Weber, A.; Schuler-Schmid, U.; Teuber, M. Microbiology and fermentation balance in a Kombucha beverage obtained from a tea fungus fermentation. Syst. Appl. Microbiol. 1995, 18, 590-594. [CrossRef]

11. Arıkan, M.; Mitchell, A.L.; Finn, R.D.; Gürel, F. Microbial composition of Kombucha determined using amplicon sequencing and shotgun metagenomics. J. Food Sci. 2020, 85, 455-464. [CrossRef] 
12. Villarreal-Soto, S.A.; Beaufort, S.; Bouajila, J.; Souchard, J.P.; Taillandier, P. Understanding Kombucha tea fermentation: A review. J. Food Sci. 2018, 83, 580-588. [CrossRef]

13. Gaggìa, F.; Baffoni, L.; Galiano, M.; Nielsen, D.; Jakobsen, R.; Castro-Mejía, J.; Bosi, S.; Truzzi, F.; Musumeci, F.; Dinelli, G.; et al. Kombucha beverage from green, black and rooibos teas: A comparative study looking at microbiology, chemistry and antioxidant activity. Nutrients 2018, 11, 1. [CrossRef]

14. Gullo, M.; La China, S.; Petroni, G.; Di Gregorio, S.; Giudici, P. Exploring K2G30 genome: A high bacterial cellulose producing strain in glucose and mannitol based media. Front. Microbiol. 2019, 10, 1-12. [CrossRef]

15. Singhsa, P.; Narain, R.; Manuspiya, H. Physical structure variations of bacterial cellulose produced by different Komagataeibacter xylinus strains and carbon sources in static and agitated conditions. Cellulose 2018, 25, 1571-1581. [CrossRef]

16. Mamlouk, D.; Gullo, M. Acetic acid bacteria: Physiology and carbon sources oxidation. Indian J. Microbiol. 2013, 53, 377-384. [CrossRef] [PubMed]

17. Jayabalan, R.; Marimuthu, S.; Swaminathan, K. Changes in content of organic acids and tea polyphenols during kombucha tea fermentation. Food Chem. 2007, 102, 392-398. [CrossRef]

18. Mamlouk, D. Insight Into Physiology and Functionality of Acetic Acid Bacteria Through a Multiphasic Approach. Ph.D. Thesis Dissertation, University of Modena and Reggio Emilia, Reggio Emilia, Italy, 2012.

19. De Vero, L.; Boniotti, M.B.; Budroni, M.; Buzzini, P.; Cassanelli, S.; Comunian, R.; Gullo, M.; Logrieco, A.F.; Mannazzu, I.; Musumeci, R.; et al. Preservation, characterization and exploitation of microbial biodiversity: The perspective of the Italian Network of Culture Collections. Microorganisms 2019, 7, 685. [CrossRef]

20. Gullo, M.; Mamlouk, D.; De Vero, L.; Giudici, P. Acetobacter pasteurianus strain AB0220: Cultivability and phenotypic stability over 9 years of preservation. Curr. Microbiol. 2012, 64, 576-580. [CrossRef] [PubMed]

21. Navarro, R.; Uchimura, T.; Komagata, K. Taxonomic heterogeneity of strains comprising Gluconacetobacter hansenii. J. Gen. Appl. Microbiol. 1999, 45, 295-300. [CrossRef] [PubMed]

22. Gullo, M.; Sola, A.; Zanichelli, G.; Montorsi, M.; Messori, M.; Giudici, P. Increased production of bacterial cellulose as starting point for scaled-up applications. Appl. Microbiol. Biotechnol. 2017, 101, 8115-8127. [CrossRef] [PubMed]

23. Hwang, J.W.; Yang, Y.K.; Hwang, J.K.; Pyun, Y.R.; Kim, Y.S. Effects of pH and dissolved oxygen on cellulose production by Acetobacter xylinum BRC5 in agitated culture. J. Biosci. Bioeng. 1999, 88, 183-188. [CrossRef]

24. Gullo, M.; De Vero, L.; Giudici, P. Succession of selected strains of Acetobacter pasteurianus and other acetic acid bacteria in traditional balsamic vinegar. Appl. Environ. Microbiol. 2009, 75, 2585-2589. [CrossRef] [PubMed]

25. Versalovic, J.; Schneider, M.; De Bruijn, F.J.; Lupski, J.R. Genomic fingerprinting of bacteria using repetitive sequence-based polymerase chain reaction. Methods Mol. Cell. Biol. 1994, 5, 25-40.

26. Versalovic, J.; Koeuth, T.; Lupski, R. Distribution of repetitive DNA sequences in eubacteria and application to fingerprinting of bacterial genomes. Nucleic Acids Res. 1991, 19, 6823-6831. [CrossRef] [PubMed]

27. Hunter, P.R.; Gaston, M.A. Numerical index of the discriminatory ability of typing systems: An application of Simpson's index of diversity. J. Clin. Microbiol. 1988, 26, 2465-2466. [CrossRef]

28. Harrell, F.E., Jr.; Dupont, M.C. R Package Hmisc; CRAN; R Foundation for Statistical Computing: Vienna, Austria, 2014. Available online: https: / /CRAN.R-project.org/package=Hmisc (accessed on 3 February 2020).

29. R Core Team. R: A Language and Environment for Statistical Computing; R Foundation for Statistical Computing: Vienna, Austria, 2017. Available online: https:/ / www.R-project.org/ (accessed on 3 February 2020).

30. Taiyun, W.; Viliam, S. R package "corrplot": Visualization of a Correlation Matrix: Version 0.84. 2017. Available online: https: / / github.com/taiyun/corrplot (accessed on 3 February 2020).

31. Battikh, H.; Chaieb, K.; Bakhrouf, A.; Ammar, E. Antibacterial and antifungal activities of black and green kombucha teas. J. Food Biochem. 2013. [CrossRef]

32. Sievers, M.; Sellmer, S.; Teuber, M. Acetobacter europaeus sp. nov., a main component of industrial vinegar fermenters in central Europe. Syst. Appl. Microbiol. 1992, 15, 386-392. [CrossRef]

33. Ludwig, W.; Klenk, H.P. Overview: A phylogenetic backbone and taxonomic framework for procaryotic systematics. In Bergey's Manual of Systematic Bacteriology, The Proteobacteria, Part A, Introductory Essays, 2nd ed.; Brenner, D.J., Krieg, N.R., Staley, J.T., Garrity, G.M., Eds.; Springer: New York, NY, USA, 2005; Volume 2, pp. 49-65.

34. La China, S.; Bezzecchi, A.; Moya, F.; Petroni, G.; Di Gregorio, S.; Gullo, M. Genome sequencing and phylogenetic analysis of K1G4: A new Komagataeibacter strain producing bacterial cellulose from different carbon sources. Biotechnol. Lett. 2020, 42, 807-818. [CrossRef]

35. Jakmuangpak, S.; Prada, T.; Mongkolthanaruk, W.; Harnchana, V.; Pinitsoontorn, S. Engineering bacterial cellulose films by nanocomposite approach and surface modification for biocompatible triboelectric nanogenerator. ACS Appl. Electron. Mater. 2020, 2, 2498-2506. [CrossRef]

36. Cleenwerck, I.; Vandemeulebroecke, K.; Janssens, D.; Swings, J. Re-examination of the genus Acetobacter, with descriptions of Acetobacter cerevisiae sp. nov. and Acetobacter malorum sp. nov. Int. J. Syst. Evol. Microbiol. 2002, 52, 1551-1558. [CrossRef]

37. Gevers, D.; Huys, G.; Swings, J. Applicability of rep-PCR fingerprinting for identification of Lactobacillus species. FEMS Microbiol. Lett. 2001, 205, 31-36. [CrossRef]

38. Švec, P.; Vancanneyt, M.; Seman, M.; Snauwaert, C.; Lefebvre, K.; Sedláček, I.; Swings, J. Evaluation of (GTG) 5 -PCR for identification of Enterococcus spp. FEMS Microbiol. Lett. 2005, 247, 59-63. [CrossRef] [PubMed] 
39. De Vuyst, L.; Camu, N.; De Winter, T.; Vandemeulebroecke, K.; Van De Perre, V.; Vancanneyt, M.; De Vos, P.; Cleenwerck, I. Validation of the (GTG) $)_{5}$-rep-PCR fingerprinting technique for rapid classification and identification of acetic acid bacteria, with a focus on isolates from Ghanaian fermented cocoa beans. Int. J. food Microbiol. 2007. [CrossRef]

40. Cleenwerck, I.; De Wachter, M.; González, Á.; De Vuyst, L.; De Vos, P. Differentiation of species of the family Acetobacteraceae by AFLP DNA fingerprinting: Gluconacetobacter kombuchae is a later heterotypic synonym of Gluconacetobacter hansenii. Int. J. Syst. Evol. Microbiol. 2009, 59, 1771-1786. [CrossRef] [PubMed]

41. Azuma, Y.; Hosoyama, A.; Matsutani, M.; Furuya, N.; Horikawa, H.; Harada, T.; Hirakawa, H.; Kuhara, S.; Matsushita, K.; Fujita, N.; et al. Whole-genome analyses reveal genetic instability of Acetobacter pasteurianus. Nucleic Acids Res. 2009, 37, $5768-5783$. [CrossRef]

42. Matsutani, M.; Nishikura, M.; Saichana, N.; Hatano, T.; Masud-Tippayasak, U.; Theergool, G.; Yakushi, T.; Matsushita, K. Adaptive mutation of Acetobacter pasteurianus SKU1108 enhances acetic acid fermentation ability at high temperature. J. Biotechnol. 2013, 165, 109-119. [CrossRef] [PubMed]

43. Pothimon, R.; Gullo, M.; La China, S.; Thompson, A.K.; Krusong, W. Conducting High acetic acid and temperature acetification processes by Acetobacter pasteurianus UMCC 2951. Process Biochem. 2020, 98, 41-50. [CrossRef] 